\title{
ПРИЧИНИ КОНФЛІКТІВ У ІЕРАРХІЧНО ОРГАНІЗОВАНИХ СУСПІЛЬНИХ СИСТЕМАХ
}

\begin{abstract}
Л.А. Білоконенко
у діалозі «Держава» Платон обгрунтував концепцію чинників виникнення держави та людського суспільства загалом, головним серед яких він вбачав потреби людей. Згідно з цією концепцією, «кожна людина залучає то одного, то другого до задоволення тієї чи іншої потреби. Маючи необхідність багато в чому, більшість людей збираються разом, щоб спільно жити та надавати один одному допомогу: таке співіснування отримало у нас назву держава» $[10,369 c]$. Отже, у будь-якому суспільстві необхідним є розподіл праці, який, у свою чергу, має відповідати основним групам людських потреб. Платон виокремив три таких групи, без задоволення яких неможливе існування ані окремої людини, ані суспільства в цілому, а саме: (1) матеріальні потреби, (2) потребу в захисті (обороні) та (3) потребу в організації суспільного життя, тобто, по суті, - в управлінні.

Слід зауважити, що управління, яке здійснюється у соціальних системах, завжди має дві основні підсистеми: (1) яка управляє і (2) яка управляється. Суб'єкт управління - це керівник, об'єкт- це підлеглий. Але у соціальних системах такий поділ досить умовний, адже ми маємо справу не просто із діадою «керівник-підлеглий», а із «особливим видом людської діяльності, котра відображає взаємодію об'єктивних і суб'єктивних факторів суспільного життя людей» [7, с. 277], і в якій не можна механічно виділити філософський, психологічний, конфліктологічний, соціологічний чи суто управлінський аспекти. Тому конфлікт між керівником та підлеглим має розглядатися у комплексі, як міждисциплінарне явище.
\end{abstract}

Метою нашої роботи $\epsilon$ визначення причин конфліктів у ієрархі-

Актуальні проблеми духовності 
чно організованих суспільних системах, а саме: у діаді «керівникпідлеглий». Конфлікт ми вивчаємо як феномен, який має об'єднувати існуючі у психології, конфліктології та менеджменті точки зору на його виникнення. У цьому полягає новизна дослідження.

Звернемося до визначення сутності управлінської діяльності, яка і здійснюється керівником. Управління базується на взаємодії трьох процесів: отримання, обробка та передача інформації. У соціальній системі управлінське рішення виробляється на основі «аналізу та оцінки інформації суб'єктом управління» $[2$, с. 6$]$. Ці рішення мають враховувати соціальні форми, які впливають на діяльність особи як представника соціальної структури та які можуть мати прояв в економічних, політичних, правових, культурологічних, педагогічних сферах.

Процес управління стає дедалі складнішим через складність життя сучасного суспільства. Швидкими темпами розвивається наука, техніка, виробництво. Тому й управління вимагає від керівника реального активного використання різних знань, серед яких мають бути i ті, що можуть забезпечити стабільне, безконфліктне існування організації, установи тощо.

Причини виникнення конфліктів між керівником та підлеглим у конфліктології об'єднано у дві групи: об'єктивні (ті, які виникли через соціальну взаємодію людей) та суб'єктивні (пов'язані з їх індивідуально-психологічними особливостями) [1, с. 107]. У психології управління причини зміщено дещо в іншу площину: управлінські та соціально-психологічні [2, с. 331-335]. Для більш грунтовного розуміння причин конфліктів поєднаємо теоретичну базу конфліктології, психології управління та менеджменту і визначимо також дві основні причини конфліктів: організаційно-управлінські, які будуть визначати принципи і методи управління, котрі призводять до конфліктів, та соціальнопсихологічні, які включають також і індивідуальні причини.

Організаційно-управлінські причини, у свою чергу, мають два різновиди: порушення принципів управління та необгрунтований вибір методів управління.

Принципи управління - це певні правила, норми чи установки, які організують процес управління, обгрунтовують управлінські функції та надають можливість вибору необхідних прийомів впливу на працівника. Загальні принципи, якими мають послуговуватися всі суб'єкти управління, $\epsilon$ чітко визначеними у теорії менеджменту та психології управління: законність, системність, гласність, об'єктивність, колегіальність у поєднанні з одноосібним керівництвом [2, с. 28-29]. Недотримання будь-якого принципу стає основою конфлікту. Зокрема, дія 
за межами норм права на основі розпоряджень керівника, місцевих норм, інтересів установи і т. п. призводить до конфлікту із законом та порушує принцип законності. Помилки при виборі способів, форм, методів впливу на об'єкт, який існує в оточенні інших систем управління, призводить до конфлікту цих систем. Недотримання принципу гласності, при якому відсутня правдива, широка інформація, призводить до недовіри до керівника, демонструє його небажання поважати працівників, розбиратися докладно у ситуаціях та свідомо і без емоцій обирати правильне рішення. Це шлях до міжособистісних конфліктів. Порушення принципу комплексності (не враховуються системно економічні, соціальні, ідеологічні, психологічні, організаційні аспекти) не дозволяє ефективно вирішувати певні задачі, призводить до некомпетентного підходу до проблем, що є умовою екстремальної діяльності установи. Принцип об'єктивності дозволяє системі, яка управляє, використовувати знання об'єктивних законів для досягнення практичних задач. Він має запобігати суб'єктивізму, волюнтаризму, свавіллю, поквапним діям, які не враховують реальну ситуацію. Ненауково обгрунтовані управлінські рішення стають основою і міжособистісних, і міжгрупових конфліктів. Ці види конфліктів мають силу і при відсутності розумного поєднання одноосібного керівництва та колегіальності. Цей принцип вимагає одночасної персональної та колегіальної відповідальності за прийняті рішення.

Методи управління являють собою етапи та процедури при підготовці та прийнятті, організації та контролю виконання управлінських рішень. Методи використовуються різні, але вони повинні бути адекватними характеру професійних задач. Кожен конкретний випадок вимагає певного методу та має відповідати особливостям діяльності суб'єкта і об'єкта управління. Практики найчастіше використовують комплекс методів для комплексності впливу. Безперечно, неправильний вибір методу, який не відповідає змісту та етапу рішення управлінської задачі, призводить не тільки до помилковості у вирішенні проблеми, але й до конфліктних дій. Одним із найконфліктніших є адміністративний метод, тобто метод владної мотивації. Він базується на підвладності порядку, закону, старшим посадовим особам і має обов'язковий характер. За допомогою цього методу діють механізми примусу, підтримується службова дисципліна, яка необхідна для виконання співробітниками своїх обов'язків. Однак зловживання цим методом (як і методом розпоряджень) часто призводить до подавлення ініціативи, самостійності мислення, відсутності оперативної реакції працівників. Це не дає їм шансу реалізувати свої можливості. 
Регламентний метод являє собою опис порядку виконання управлінських рішень, розподілення задач між виконавцями. Якщо керівник не встановлює чіткі правила діяльності суб'єктів управління, не враховує психологічні та професійні здібності людей, то виникають помилки у роботі, які можуть призвести до конфлікту між підрозділами, службами тощо.

Мотиваційний метод, методи матеріального та морального стимулювання є заохочувальними діями з боку керівника, який за допомогою підвищення посадового окладу, премій, нагород (матеріальних і нематеріальних) сприяє кращому виконанню управлінських рішень. Порушення, з точки зору працівників, принципу справедливості при застосуванні цих методів призводить до міжособистісних непорозумінь та породжує внутрішньогруповий фаворитизм.

Отже, порушення принципів управління, зловживання чи неправильне використання певних методів стає на заваді оптимізації взаємин суб'єктів управління. Соціальні, психологічні фактори також впливають на людські стосунки. В управлінні все частіше враховується широкий спектр психологічних особливостей особи та її індивідуальні властивості. Психологи з теорії організації праці переключили свою увагу із суті людських взаємовідносин на налагодження міжособистісних стосунків. Фактично, йде мова про «соціальне управління - це управління людьми, і воно повинно базуватися на врахуванні закономірностей людських відносин» [2, с. 42].

Управління - це процес, у якому провідною ланкою $\epsilon$ керівник, адже саме він добирає кадри, дбає про продуктивність роботи та психологічний клімат колективу. Найважливішою характеристикою діяльності керівника $€$ його стиль управління - система методів та прийомів управлінської діяльності, які керівник обирає найчастіше. Цей вибір визначається рядом об'єктивних та суб'єктивних чинників. Об'єктивними є виробничі, правові, політичні та інші аспекти діяльності установи, складність задач, умов їх виконання. Суб'єктивні-темперамент, риси характеру, здібності людини, звичка до певного виду діяльності, до спілкування. Тому стиль управління містить у собі і організаційно-управлінські, і соціально-психологічні причини, які призводять до конфліктів.

Психологи вирізняють три основні стилі управління, які визначаються методами аналізу та виконання рішень, формами взаємодії 3 підлеглими та мірою контролю за їх діяльністю.

Авторитарний стиль характеризує надмірну концентрацію влади в одних руках. Такий стиль доречний у випадках, коли необхідно швид- 
ко обирати рішення, коли воля, натиск, характер керівника стають запорукою оптимальної діяльності в екстремальних умовах. Та установа не існує весь час в екстремальних умовах. Але керівник такого типу на це не зважає - він звик самостійно приймати рішення, вимагати їх чіткого виконання, ідеального порядку, не потребує порад, запроваджує суворий психологічний клімат у колективі та вимогливий без поблажливості. Кращий варіант такого керівника, коли і відповідальність за свою діяльність (у тому числі і неправильну) він приймає на себе. Гірший - коли серед підлеглих визначається винний.

Демократичний стиль має подвійну основу: особистий та діловий авторитет керівника. Він доречний в управлінні навчальними закладами, творчими колективами, рекламними агенціями тощо, тобто там, де психологічний клімат відіграє значну роль. Керівник-демократ активно залучає до роботи своїх помічників, створює ініціативні групи, визнає свободу думки працівника, не дистанціюється від колективу, тактовний, терплячий. Але остаточне рішення завжди залишається за ним.

Ліберальний стиль керівництва базується на довірі до виконавців, на свободі дій у межах їх функціональних обов'язків. Стиль доречний у колективі артистів, на кафедрі навчального закладу, в науково-дослідному інституті тощо. Керівник такої структури сприймається як наставник, порадник, лідер. Він тактовна, спокійна і неконфліктна людина, невимогливий, опирається у роботі на помічників, може приймати рішення під впливом колективу. А колектив, у свою чергу, має високий рівень самосвідомості і самоорганізації. Якщо керівник-ліберал не має особливих творчих чи наукових здібностей, то діє він в основному формально, безініціативно.

На стиль управління впливають індивідуальні риси керівника, тому стиль визнається як суб'єктивність в об'єктивних формах діяльності.

Розуміння керівником підлеглого теж містить умови для конфлікту: поверхневий рівень визначає лише загальне сприйняття людини, яка часто сприймається лише як «хороша» чи «погана». А високий рівень виявляє зв'язок між мотивами і цілями особи та її сприйняттям взагалі. Для керівника важливим і необхідним є саме високий рівень розуміння, який сприяє самостійності, творчій діяльності працівників, $є$ запорукою гнучкої неконфліктної поведінки.

Стиль управління має враховувати і міжособистісні стосунки в колективі, які формують його психологічний клімат. Людина у групі обов'язково отримує «соціометричний статус» зі своєю градацією. У колективі працівники мають свій статус, і саме він визначає ставлення до 
особи. На основі міжособистісних стосунків створюються неформальні групи. Керівник має співпрацювати з цими групами, котрі об'єднують людей зі спільними справами, задачами, інтересами. Поєднання працівників різних груп може не тільки стати на заваді виконання завдань установи, але й створити умови для конфліктних ситуацій.

Принцип спілкування є особливим для людини. Інформація завжди має особистісну значимість та сенс. Комунікативний процес в умовах людського спілкування зазнає якісних та кількісних змін. Тому при передачі інформації керівник має враховувати, що працівники можуть мати свої мотиви, мету, життєві установки і т. п., тому ця інформація гранично стає новою. Люди намагаються впливати один на одного. А ефективність цього впливу буде реальною тоді, коли особи мають схожі або близькі мотиви дії. Тому у процесі спільної діяльності суб'єкти спілкування, для безконфліктного існування, повинні мати і однакове розуміння ситуації спілкування, і близьке сприйняття інформації, i ідентичні лексичні та синтаксичні системи.

До конфлікту може призвести неточний вислів, недостатність словникового запасу, невміння сформулювати управлінське рішення. Через брак часу губиться значна частина інформації, а ще частина особою не сприймається. Міжособистісне спілкування визначається й тим, що певна інформація існує на рівні позасвідомого, не може бути практично передана словами. Інколи людина не бажає подавати всю інформацію, а в певних ситуаціях співрозмовник цю інформацію просто не розуміс.

Для уникнення конфліктів керівник має, перш за все, враховувати всі особливості інформаційно-комунікативної функції спілкування. Із свого боку дбати про точність, інформативність, зрозумілість управлінських рішень, обирати правильно темп мовлення, використовувати додатково невербальні засоби; не вважати, що якась частина інформації «і так зрозуміла»; завжди пам'ятати - на основі однієї інформації різними працівниками можуть бути зроблені не просто різні, а протилежні висновки.

Процес спілкування включає і перцептивну функцію, яка визначає формування суб'єктом образу іншої людини. Намагаючись пізнати, зрозуміти іншого, людина бажає скласти уявлення про його думки, наміри, здібності, установки: сприйняти у соціально-психологічному плані. Цей процес відображає і зовнішні риси індивіда, і розуміння його поведінки, його життєвих установок. Найпростіший спосіб пізнання іншої людини - ідентифікація, складніший - рефлексія. Для керівника важливим $є$ розуміння того, як його сприймають працівники, адже 
невірна уява про їх взаємодію не лише створить проблеми у спілкуванні, а й буде на заваді аналізу рефлексивної структури групи. Безперечно, це створить умови для конфліктних ситуацій.

До соціально-психологічних причин виникнення конфліктів належить і фактор психологічної здібності до професії. Кожна людина може оволодіти майже будь-якою професією, але для цього різним особам необхідно різний час, різна сила, але - непередбачувана результативність. Хоча людина здатна активно пристосовуватися до багатьох професій, та є професії, які до організації особистості висувають підвищені вимоги. Фахівці з управління визначають професії першого типу, для оволодіння якими люди повинні мати спеціальні індивідуальні риси, та другого, з якими може впоратися практично будь-хто [5]. Людина виявляє свої індивідуальні особистісні якості у процесі професійного навчання i виробничої діяльності, тому знання і врахування керівником цих якостей - необхідна умова їх безконфліктного спілкування.

Психограми визначають властивості особистості і дають можливість їх ранжування. Нам психограма цікава через її здатність виявити, які риси мають бути у керівника, щоб можна було говорити про його психологічні здібності до управління. 316 властивостей найвищий рівень вимог мають: самоконтроль, воля, інтуїція, економічне чуття, здатність до лідерства, комунікабельність, самовладання, увага. Дещо нижчий рівень: терпимість, щирість, педантизм, допитливість, аналітичний склад розуму, пам'ять, багата уява. Вимога до такої властивості як здатність до виконання рутинної роботи практично дорівнює нулю (див.: [2]).

Таким чином, сам керівник повинен мати певні психологічні властивості для здійснення управлінських функцій. Враховувати здібності працівників, що важливо для індивідуального підходу до виконавця, для корекції його професійної діяльності. Порушення в цій ланці буде блокувати виконання управлінських рішень і провокуватиме конфлікт.

У системі управління мають враховуватися також індивідуальнопсихологічні властивості працівників. Це, перш за все, темперамент, характер та здібності особи. Врахування властивостей темпераменту важливе при професійному відборі до певних видів діяльності, наприклад, при переробці інформації, при прийнятті важливих рішень, при необхідності особливої уважності тощо. Так як темперамент $є$ постійна природна основа особи, то керівник не має намагатися ㄲï «перевиховувати», а знаходити ті обов'язки, у реалізації яких людина найбільше себе проявляє. На жаль, керівники не часто вдаються до визначення 
типу темпераменту своїх працівників, що призводить до нервово-психічних затрат, втрачається час, псуються стосунки, але в результаті виконавці все одно проявляють різну надійність у різних видах робіт, різні можливості своєї діяльності, які не змінити.

На відміну від темпераменту характер є результатом розвитку особистості та визначає її ціннісну орієнтацію. Існують характери з інтелектуальними (критичність, спостережливість), емоційними (чесність, щирість) та вольовими (принциповість, наполегливість) рисами. Структура характеру визначає ставлення до інших людей, до себе, до діяльності, до колективу. Важко чекати результативного виконання управлінського рішення від людини, яка за складом свого характеру $є$ недовірливою, гордою, безвідповідальною чи безпринципною. Якщо до цих рис додається ще й екзальтованість, неадекватні реакції, то можна говорити про явні конфліктні ситуації.

Здібності не є готовим природним даром людини, адже вони потребують тренування, виховання тощо. Кожен керівник хотів би бачити у своїй команді талановитих чи геніальних людей. Але їх небагато, тож необхідно працювати з наявним людським матеріалом. Найважливішим є визначення у працівників виконавських чи творчих здібностей та їх врахування при розподілі завдань. Помилка керівника у характеристиці виду здібностей призведе до негативного вирішення виробничих задач.

Безконфліктні міжособистісні стосунки у колективі визначаються і певними формами взаємовідносин. Не будемо говорити про вирішення конфліктів із «звичайними» людьми. Проблемою є люди, які навмисно ніколи не підуть на поступки. Це так звані «важкі люди», котрі мають свої особистісні характеристики і потребують спеціальних підходів у спілкуванні з ними. Керівники зазвичай намагаються позбутися таких працівників, але це не завжди можливо чи доречно. Тож необхідно вміти співпрацювати з «важкими людьми», використовуючи певні правила та переборюючи негативні емоції, які виникають при спілкуванні з ними.

Кожен тип «важких людей» $є$ потенційним провокатором конфлікту. Класифікації цих типі $є$ різні, але в узагальненому виді їх називають таким чином: агресивісти (ображають та зачіпають інших), скаржники (нічого не роблять, не беруть на себе відповідальність), мовчуни (приховують свої думки), песимісти (вважають, що ні на що не здатні), знавці (переконані, що знають все), нерішучі (бояться помилитися), брехуни (обманом виправдовують себе), потайливі (тримають образу в собі, а потім «вибухають» гнівом), гравці (діють та 
думають по-різному) [2, с. 129-130]. Для керівника найбільш ефективним є принцип спілкування з ними, коли він визнає існування певних прихованих інтересів чи потреб працівників, які вони задовольняють подібним чином. Важко чекати від керівника особливого прилаштування до «важких людей», але при необхідності можна хоча б подумати, чим ці потреби задовольнити? Тоді вирішення конфліктів за їх участю не буде відрізнятися від конфліктів із «звичайними» працівниками.

Спілкування з «важкими людьми» завдає керівнику незручностей і в емоційній сфері, викликаючи гнів, пригнічення, завдаючи прикростей. Тому керівник має тримати під контролем свої емоції, пам'ятати про психологічні установки i, по можливості, відкрито обговорювати причини поведінки таких людей. Це дає можливість нейтралізувати чи взяти під контроль працівника. У разі неможливості застосування будь-яких підходів керівник навряд чи буде прагнути до безконфліктного співіснування.

Прагнення до влади також є безперечною причиною конфлікту, адже керівництво - це, перш за все, влада. Тому посягання на владу $\epsilon$ фактичним зазіханням на статус керівника.

До соціально-психологічних включаємо й індивідуальні причини: низька культура спілкування, грубість, несумлінність у виконанні службових обов'язків підлеглими, бажання керівника ствердити свій авторитет, негативна установка керівника по відношенню до підлеглого, підвищена емоційність осіб, тривожність, акцентуації характеру тощо.

Отже, як було визначено, конфлікт між керівником та підлеглим може визначатися організаційно-управлінськими та соціально-психологічними причинами. Ці причини мають комплексний характер та можуть виявлятися у різних варіантах поєднання. Описані причини об'єднують існуючу теорію конфлікту та принципи управління, які визначені сучасними фахівцями з психології управління та менеджменту.

Підводячи підсумок, дозволимо собі висловити переконання, що керівник не має за будь-яку ціну уникати конфліктів чи боятися їх. Конфлікт - реальне явище людського життя. Та співпрацювати краще із партнером, адже, як стверджує Ю. Хабермас: «Будь-яка взаємодія, будь-який діалог партнерів ... є результат досягнення розуміння».

\section{1 Бібліографія}

[1] Аниупов A.Я., Баклановский С.В. Конфликтология в схемах и комментариях. - Спб.: ПИТЕР, 2005. 
[2] Бандурка A.M., Бочарова С.П., Землянская Е.В. Психология управления. - Харьков, 1998.

[3] Беседін M.O., Нагаєв В.М. Основи менеджменту.-К.: Центр навч. л-ри, 2005.

[4] Глухов В.В. Менеджмент. - Спб.: ПИТЕР, 2005.

[5] Гуревич K.M. Профессиональная пригодность и основные свойства нервной системы. - М.: Знание, 1970.

[6] Гришина Н.В. Психология конфликта.-Спб.: ПИТЕР, 2005.

[7] Завадсъкий Й.С. Менеджмент. - К.: УФІМБ, 1997.-Т. 1.

[8] Inamов E.Ф., Левківський К.М., Павловський В.В. Психологія управління в бізнесі. - Харків-Київ: НМЦВО, 2003.

[9] Мартиненко М.М. Основи менеджменту. - К.: Каравела, 2005.

[10] Платон. Государство // Соч. в 4-х томах. - М.: Мысль, 1994.T. 3.

[11] Свенцицкий A.Л. Социальная психология управления. - Л.: Издво ЛГУ, 1980. 